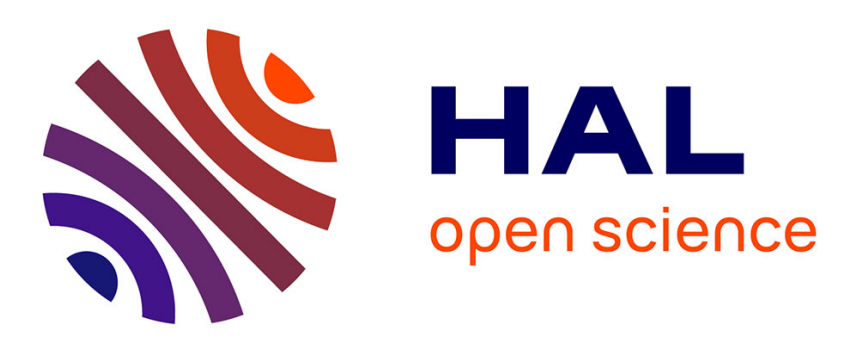

\title{
Humins in the environment: early stage insights on ecotoxicological aspects
}

\author{
Anitha Muralidhara, Anne Bado-Nilles, Guy Marlair, Victor Engelen, \\ Christophe Len, Pascal Pandard
}

\section{To cite this version:}

Anitha Muralidhara, Anne Bado-Nilles, Guy Marlair, Victor Engelen, Christophe Len, et al.. Humins in the environment: early stage insights on ecotoxicological aspects. Biofuels, Bioproducts \& Biorefining, 2018, 13 (3), pp.464-470. 10.1002/bbb.1964 . ineris-02614295

\section{HAL Id: ineris-02614295}

\section{https://hal-ineris.archives-ouvertes.fr/ineris-02614295}

Submitted on 20 May 2020

HAL is a multi-disciplinary open access archive for the deposit and dissemination of scientific research documents, whether they are published or not. The documents may come from teaching and research institutions in France or abroad, or from public or private research centers.
L'archive ouverte pluridisciplinaire HAL, est destinée au dépôt et à la diffusion de documents scientifiques de niveau recherche, publiés ou non, émanant des établissements d'enseignement et de recherche français ou étrangers, des laboratoires publics ou privés. 


\title{
Humins in the environment - Early stage insights on ecotoxicological aspects
}

Anitha Muralidhara, ${ }^{\mathrm{a}, \mathrm{b}, \mathrm{c}}$ Anne Bado-Nilles, ${ }^{\mathrm{a}}$ Guy Marlair, ${ }^{\mathrm{a}}$ Victor Engelen, ${ }^{\mathrm{b}}$ Christophe Len, ${ }^{\mathrm{c}, \mathrm{d}}$ and Pascal Pandard ${ }^{a *}$

${ }^{a}$ Institut National de l'Environnement Industriel et des Risques (INERIS) Parc technologique Alata, BP 2, Verneuil-en-Halatte, F-60550, Verneuil en Halatte, France

${ }^{\mathrm{b}}$ Avantium Chemicals B.V., Zekeringstraat 29, 1014 BV Amsterdam, The Netherlands

c Sorbonne Universités, Université de Technologie de Compiègne, Centre de Recherche Royallieu, CS 60 319, F-60203 Compiègne cedex, France

d PSL Research University, Chimie ParisTech, CNRS, Institut de Recherche de Chimie Paris, 11 rue Pierre et Marie Curie, F-75231 Paris cedex 05, France.

\section{KEYWORDS}

Humins, furanics, ecotoxicity, immunomarkers, biodegradability, byproduct valorization

\begin{abstract}
With the growing interest of a circular economy, the use of lignocellulosic residues such as lignins and humins as potential renewable feedstock for biorefining processes looks more and more promising. With humins, many challenges are still remaining for their sustainable use, starting from the need of providing reference data reflecting actual usable feedstocks of such materials. With this perspective, this paper offers a first outlook on the potential environmental fate of those materials and components, all related to furanics, a family of compounds for which toxicity is still a matter of debate.

During the assessment, the conventional OECD ecotoxicity and biodegradability tests demanded by the European REACH regulation for a primary evaluation of environmental hazards were performed in combination with fish immunomarker tests to study the possible long-term effects on aquatic ecosystems. These first results are promising as humins did not exhibit any immediate ecotoxicological concerns and hence would allow considering their use in environmental-friendly applications.
\end{abstract}

\section{INTRODUCTION}

Furanic compounds have recently drawn noticeable techno-economic interest due to the their production from non-edible parts of lignocellulosic biomass to produce fuels, chemicals and materials. ${ }^{1}$ For this very reason, some of these furanic compounds have been listed by the U.S Department of Energy as one of the top 12 and top 30 high potential chemical building blocks. ${ }^{2}$ In a similar context, Avantium's YXY® process produces 2,5-Furandicarboxylic acid (FDCA) for the development of bio-plastics. ${ }^{3}$ FDCA production process primarily involves the dehydration of carbohydrates (C6 and C5 sugars) into alkoxymethyl furfural (RMF). ${ }^{1,4}$ 
RMF is the furanic intermediate mixture essentially composed of methoxymethyl furfural (MMF) and 5-hydroxymethyl furfural (HMF). Besides leading to various furanics and other platform chemicals, the Acid Catalysed Dehydration (ACD) process also leads to the production of an unavoidable side stream residue called humins. ${ }^{5}$

Humins are polyfuranic macromolecule mixtures with minor quantities of furanic derivatives retained in their structure. ${ }^{6,7}$ The chemical structure of humins is highly complex and largely depends on the type of feedstock, operating conditions and the functional groups associated with it. ${ }^{8,9}$ Despite existing for many decades, humins, until today, have been used only as residues in low value applications such as combustion and gasification. ${ }^{10}$ With the primary aim of upgrading biorefinery side streams to improve bio-based economics in the recent past, innovative potential application for humins as renewable raw materials have been identified mainly in catalysis, water purification, matrix of impregnation materials, $\mathrm{CO}_{2}$ sequestration and energy storage. ${ }^{11-14}$

The complex structure of humins certainly indicates highly variable physico-chemical properties, and in turn gives an indication of the potentially varying risk profiles that need to be anticipated for their sustainable new use. Besides understanding these aspects, it is equally important to recognize the nature and properties of the most important compounds present throughout the entire production chain of humins.

Although MMF and HMF have been independently addressed by various researchers so far, their effect as a mixture has not been studied together. Also noteworthy, neither humins nor RMF is yet assessed and classified according to the international Classification and Labelling System of Chemicals such as the CLP regulation in the EU (derived from the Globally Harmonised System of Classification and Labelling of Chemicals (GHS) ${ }^{15}$ ) or according to the United Nations Model Regulations for the Transport of Dangerous Goods (UN TDG). ${ }^{16}$ Thus, very limited or almost no safety related information of humins or RMF mixtures is available for the end user, indicating that the materials are still in the early stage research. ${ }^{6}$

Bio-based nature humins and furanic intermediates and/or platform chemicals does not necessarily provide safe attributes to these materials in all working environments. ${ }^{17}$ Considering potentially the vast amounts of production and broad application routes being explored, it is important to strengthen the sustainable application pathways, for which availing information on their safety profiles plays a key role. Currently, there is a lack of information regarding the persistence of these materials in the environment and their possible effects or consequences which seems to be the main concern as perceived from the literature sources. ${ }^{6,18}$

The current study as part of the EU funded HUGS project ${ }^{19}$ is focusing exclusively on addressing the ecotoxicological and biodegradation properties of humins and other key furanic intermediates namely HMF, MMF and RMF and an important side-stream methyl levulinate (ML). The proposed assessment is based on the output of a dual experimental approach combining conventional OECD ecotoxicity and biodegradability tests as demanded by REACH regulation for a first appraisal of environmental hazards and the examination of several immunomarkers in fish cells to document possible long-term effects of studied substances on the aquatic ecosystem. 


\section{MATERIALS AND METHODS}

Tests required for the annex VII of REACH regulation (1-10 tonnes/year) (i.e. (a) Algal growth inhibition test (OECD 201), ${ }^{20}$ (b) Daphnia magna acute immobilisation test (OECD 202), ${ }^{21}$ and (c) ready biodegradability test (OECD 301F) ${ }^{22}$ have been performed for ML, HMF, MMF, RMF and humins. They are presented briefly in Table 1.

Further details on humins samples and other selected compounds have been made available in a parent work of the same team. ${ }^{34}$

The selected biodegradability test is a stringent test for which a positive result will allow concluding that the chemical will degrade ultimately and quickly in the environment. Water solubility of stock solutions was confirmed by Total Organic Carbon (TOC) analysis, by comparing the TOC measurement with theoretical organic content of the selected compound.

For the Daphnia magna test, results are expressed as EC50 48h (i.e., the concentration that immobilizes $50 \%$ of daphnids within 48 hours). In Pseudokirchneriella subcapitata test, results are expressed in terms of EC10 and EC50 (i.e. effective concentration of the substrate at which either $10 \%$ or $50 \%$ of the test population are affected respectively). The algal growth inhibition test is a multi-generation test. However, for risk assessment purposes and derivation of Predicted No-Effect Concentrations (PNECs), the EC50 is treated as a shortterm toxicity value. The EC10 may be used as an additional long term result when other longterm data are available. Effective Concentration (EC) values have been calculated using a logistic Hill model with bootstrap estimation of confidence intervals. Calculations have been performed with REGTOX software. ${ }^{23}$

In addition to the tests detailed above, immunotoxicity tests ${ }^{24}$ were also conducted to develop a first approach concerning positive or negative effects on the ecosystem. Forty adult sticklebacks (Gasterosteus aculeatus, $5.3 \pm 0.3 \mathrm{~cm}, 2.0 \pm 0.4 \mathrm{~g}$ ), obtained from one spawn in INERIS husbandry facility, were used. Before experiments, the fish were maintained in a laboratory tank and fed daily with frozen red mosquito larvae and brine shrimp. Each fish was sacrificed by cervical dislocation, measured and weighed. Splenic leucocyte isolation was made following further protocols. ${ }^{25}$ Each leucocyte suspension was adjusted at $10^{6}$ cells $\mathrm{mL}^{-1}$ before incubation at $4{ }^{\circ} \mathrm{C}$ for $16 \mathrm{~h}$ with RMF, HMF, Humins b or ML with concentration ranging from 0 to $500 \mathrm{mg} \mathrm{L}^{-1} .{ }^{26}$ Then, leucocyte distribution, cellular mortality (apoptotic and necrotic leucocytes), leucocyte respiratory burst, ${ }^{27}$ lysosomal presence ${ }^{25}$ and phagocytosis activity $^{28}$ analyses were carried out on all leucocytes, using a Cyan ${ }^{\mathrm{TM}} \mathrm{ADP}$ flow cytometer (Beckman Coulter). Statistical analyses were performed using XLStat 2008 (Addinsoft). After verification of normality (Anderson-Darling test) and of homogeneity of covariance matrices (Bartlett test), a one-way ANOVA and a Student Newman-Keuls post-hoc tests were performed to assess the effect of each pollutant at each concentration in relation to control values. All hypotheses were tested for statistical significance at the level of $p \leq 0.05$. 


\section{RESULTS AND DISCUSSION}

The results of the ecotoxicity and biodegradability tests required for the annex VII of REACH regulation are summarized in Table 2. Among all the tested compounds, median effective concentrations highlighted the lack of short-term toxicity of ML, towards Daphnia magna and Pseudokirchneriella subcapitata tests (EC50s $>500 \mathrm{mg} . \mathrm{L}^{-1}$ ). These results are consistent with the daphnia test results conducted by Lomba et al., ${ }^{29}$ where the EC50 24h was 2,761 \pm 512 mg.L $\mathrm{L}^{-1}$. Irrespective of the duration of exposure, these values confirm that ML is a chemical causing no short-term toxicity effects. Regarding humins, the range of EC50 48h values for the 2 batches ( $\mathrm{Ha}$ and $\mathrm{Hb}$ with compositions $\mathrm{C}=53.4 \%, \mathrm{H}=5.9 \%, \mathrm{O}=39.7 \%$ and $\mathrm{C}=53.59$ $\%, \mathrm{H}=5.88 \%$ and $\mathrm{O}=40.2 \%$ respectively) highlighted no short-term toxicity effects towards Daphnia magna. Despite containing varying quantities of furanics in their structure, humins in general resulted in lack of short-term toxicity compared to other furanics tested independently. Whereas, EC50 value for HMF, MMF and RMF ranged from 13 to $36.5 \mathrm{mg}$. $\mathrm{L}^{-}$ 1 , globally indicating the same range of toxic effects for compounds with a similar chemical structure (i.e. presence of a furan ring and aldehyde as one of the common functional groups). Remarkably, for these three compounds a significant increase in inhibitory effects between 24 hours and 48 hours of exposure is observed. This reveals that comparison of EC50 values, in particular for such compounds, must be based on the same duration of exposure.

In contrast with D. magna mobility test, the EC50 values for $P$. subcapitata ranged in a significantly narrower interval between the highest and lowest toxic compound (i.e. 51.5 $110.2 \mathrm{mg} . \mathrm{L}^{-1}$ ), making it difficult to draw firm conclusions on the respective toxicity of tested compounds. Such findings were observed also by Lomba et al., ${ }^{29}$ and Roberts et al., ${ }^{30}$ where similar compounds tested with different species resulted in varying levels of observed toxicity. Variations in structural and functional properties of chemicals, alkyl chain lengths, responses of similar chemicals between different species were some of the common observations made from their results, which reasonably correlate in our case as well. From this it is evident that, the toxicity profiles of tested compounds can be both species and exposure dependent.

Regarding immune responses of humins and related compounds, major effects concerned inflammatory processes ${ }^{31}$ whereas the innate immune response seems to be weakly impacted. In the present work, for whatever immune parameters tested in stickleback splenocytes, no effect was detected, regardless of products and test concentrations (from 0 to $500 \mathrm{mg}$. $\mathrm{L}^{-1}$ ). Moreover, the immune values were in line with classic proportions of granulocytesmonocytes $(24.4 \pm 6.5 \%)$ and lymphocytes $(75.6 \pm 6.5 \%)$ and to basal phagocytic activity (47.9 $\pm 4.5 \%$ of phagocytic capacity; $20.2 \pm 6.5 \%$ of phagocytic capacity; $1.2 \pm 0.8$ for respiratory burst index; $4.3 \pm 0.7$ MFI for lysosomal presence) previously observed. ${ }^{24,28,32}$

As shown in Figure 1, biodegradability data made it possible to distinguish three groups of compounds: i) ML and 5-HMF which can be classified as readily biodegradable as they reached the pass level (i.e. $60 \%$ theoretical oxygen demand in a 10-day window within the 28 day period of the test); ii) the two batches of humins ( $\mathrm{Ha}$ and $\mathrm{Hb}$ ) for which some biodegradation was observed (\% biodegradation ranging between 35 and 40\%) and iii) MMF and RMF which showed no significant sign of biodegradation. For RMF, the inhibition 
control, containing both the test compound and aniline (reference compound) confirmed that RMF was not toxic for the activated sludge used as inoculum. This finding allowed concluding that the lack of biodegradation could not be attributed to an inhibitory effect on the activated sludge. The measurements of TOC removal at the end of the test confirmed the results calculated from the oxygen consumption for the whole set of compounds.

Interestingly, similar results have been obtained for each type of ecotoxicity and biodegradation test conducted for the two different batches of humins ( $\mathrm{Ha}$ and $\mathrm{Hb}$ ). These findings reveal that the slight variations observed in the composition of humins do not result in a significant variation of their ecotoxicological profile.

Eventually, an attempt was made to summarize the most significant and discriminating results of our study in Figure 2 (i.e. Daphnia magna immobilisation test and biodegradation test). They highlight that MMF and RMF (left part of the figure) could be the compounds of concern as they showed some toxicity for aquatic organisms and a lack of ready biodegradability. Our results are in accordance with the data publicly available in the ECHA's chemicals database for MMF where this compound is classified as toxic to aquatic life with long lasting effects (H411, acute chronic 2). ${ }^{33}$ Accordingly, given the fact that these compounds of concern are generally present as impurities in humins ${ }^{34}$, better environmental footprint might be targeted by minimizing their presence in crude humins. In this manner, larger portfolio of sustainable uses of these biobased feedstocks could be developed.

\section{CONCLUSIONS}

Limited knowledge of the characteristics and physico-chemical properties of humins probably caused them to be used in the past only in low value applications and visibly no efforts were made in providing enough data regarding their environmental attributes. With promises of future commercial products emerging from humins, fulfilling the existing data gaps is therefore a priority from the production, regulatory and end user perspectives. The preliminary assessment shows that industrial humins produced by $\mathrm{YXY}{ }^{\circledR}$ process do not display any immediate ecotoxicological concerns so far, thereby displaying some safer margins for further applications. As a word of caution, environmental fate of chemicals is purely species and exposure dependent, as is evidenced in the case of HMF, MMF and RMF. Therefore, due care must be taken before generalizing the hazards of a specific chemical tested with various species. Nevertheless, in the long run, there is a definite scope for in-depth safety-oriented research with further optimization of humins production pathways and newly targeted applications. In this context, research has already started to address thermal and fire hazards of these chemicals to complete the overall assessment of their safety profiles.

\section{Conflicts of interest}

There are no conflicts to declare. 


\section{Acknowledgements}

This work has been funded by the European Commission as part of a H2020 MSCA project named HUGS under the grant agreement \# 675325.

The authors are thankful to Synvina CV for supplying humins, RMF, MMF and ML samples.

\section{Bibliography}

[1] De Jong E, Gruter G-J. Furanics: A novel diesel fuel with superior characteristics. SAE 2009 Powertrains Fuels Lubr Meet FFL 2009, 2 November 2009, San Antonio, TX; United States.

[2] Werpy, T., and Petersen, G. Top Value Added Chemicals from Biomass: Volume I -Results of Screening for Potential Candidates from Sugars and Synthesis Gas. United States: N. p., 2004. Web. doi:10.2172/15008859.

[3] Avantium Chemicals BV. https:/www.avantium.com/yxy/yxy-technology/ [accessed December 14, 2017].

[4] De Jong E, Dam MA, Sipos L, Gruter G-JM. Furandicarboxylic Acid (FDCA), A Versatile Building Block for a Very Interesting Class of Polyesters. Biobased Monomers, Polymers, and Materials, 1:1-13 (2012).

[5] Van Zandvoort I, Wang Y, Rasrendra CB, Van Eck ERH, Bruijnincx PCA, Heeres HJ, et al. Formation, molecular structure, and morphology of humins in biomass conversion: Influence of feedstock and processing conditions. ChemSusChem 6:174558 (2013).

[6] Synvina CV. Personal communication Humins 2017 [accessed August 10, 2017].

[7] Pin JM, Guigo N, Mija A, Vincent L, Sbirrazzuoli N, Van Der Waal JC, et al. Valorization of biorefinery side-stream products: Combination of humins with polyfurfuryl alcohol for composite elaboration. ACS Sustain Chem Eng 2:2182-90 (2014).

[8] Wang S, Lin H, Zhao Y, Chen J, Zhou J. Structural characterization and pyrolysis behavior of humin by-products from the acid-catalyzed conversion of C6 and C5 carbohydrates. J Anal Appl Pyrolysis 118:259-66 (2016).

[9] van Zandvoort I, Koers EJ, Weingarth M, Bruijnincx PCA, Baldus M, Weckhuysen BM. Structural characterization of $13 \mathrm{C}$-enriched humins and alkali-treated $13 \mathrm{C}$ humins by 2D solid-state NMR. Green Chem 17:4383-92 (2015).

[10] Hoang TMC, Lefferts L, Seshan K. Valorization of humin-based byproducts from biomass processing - A route to sustainable hydrogen. ChemSusChem 6:1651-8 (2013).

[11] Gajic A, Koch HJ, Marlander B. HTC-biochar as a soil conditioner - first results from a 
field trial with sugar beet. Zuckerindustrie 136:791-9, (2011).

[12] Hu B, Wang K, Wu L, Yu S-H, Antonietti M, Titirici M-M. Engineering Carbon Materials from the Hydrothermal Carbonization Process of Biomass. Adv Mater 22:813-28 (2010).

[13] Mija A, van der Waal JC, Pin J-M, Guigo N, de Jong E. Humins as promising material for producing sustainable carbohydrate-derived building materials. Constr Build Mater 139:594-601 (2016).

[14] Filiciotto L, Balu AM, Van der Waal JC, Luque R. Catalytic insights into the production of biomass-derived side products methyl levulinate, furfural and humins. Catal Today 302: 2-15 (2018).

[15] UNECE, Globally Harmonized System of Classification and Labelling of Chemicals (GHS) Seventh revised edition. https://www.unece.org/trans/danger/publi/ghs/ghs_rev07/07files_e0.html [accessed March 26, 2018]

[16] UNECE, UN Recommendations on the Transport of Dangerous Goods - Model Regulations Nineteenth revised edition. https://www.unece.org/trans/danger/publi/unrec/rev19/19files_e.html [accessed March 26, 2018].

[17] Ventura SPM, de Morais P, Coelho JAS, Sintra T, Coutinho JAP, Afonso CAM. Evaluating the toxicity of biomass derived platform chemicals. Green Chem 18:473342 (2016).

[18] Synvina CV. Personal Communication Crude MMF 2017 [accessed August 15, 2017].

[19] European Commission http://cordis.europa.eu/project/rcn/198284_en.html [accessed March 12, 2018].

[20] OECD, Test No. 201: Freshwater Alga and Cyanobacteria, Growth Inhibition Test. 2011. https://www.oecd-ilibrary.org/environment/test-no-201-alga-growth-inhibitiontest_9789264069923-en [accessed March 12, 2018].

[21] OECD, Test No. 202: Daphnia sp. Acute Immobilisation Test. https://www.oecdilibrary.org/environment/test-no-202-daphnia-sp-acute-immobilisationtest_9789264069947-en [accessed March 12, 2018].

[22] OECD. Test No. 301: Ready Biodegradability. https://www.oecdilibrary.org/environment/test-no-301-ready-biodegradability_9789264070349-en [accessed March 12, 2018].

[23] REGTOX Weblet Importer http://www.normalesup.org/ vindimian/en_index.html [accessed May 1, 2018].

[24] Bado-Nilles A, Diallo AO, Marlair G, Pandard P, Chabot L, Geffard A, et al. Coupling 
of OECD standardized test and immunomarkers to select the most environmentally benign ionic liquids option-Towards an innovative "safety by design" approach. $J$ Hazard Mater 283:202-10 (2015).

[25] Bado-Nilles A, Betoulle S, Geffard A, Porcher J-M, Gagnaire B, Sanchez W. Flow cytometry detection of lysosomal presence and lysosomal membrane integrity in the three-spined stickleback (Gasterosteus aculeatus L.) immune cells: applications in environmental aquatic immunotoxicology. Environ Sci Pollut Res 20:2692-704 (2013).

[26] Bado-Nilles A, Techer R, Porcher JM, Geffard A, Gagnaire B, Betoulle S, et al. Detection of immunotoxic effects of estrogenic and androgenic endocrine disrupting compounds using splenic immune cells of the female three-spined stickleback, Gasterosteus aculeatus (L.). Environ Toxicol Pharmacol 38:672-83 (2014).

[27] Bado-Nilles A, Jolly S, Porcher J-M, Palluel O, Geffard A, Gagnaire B, et al. Applications in environmental risk assessment of leucocyte apoptosis, necrosis and respiratory burst analysis on the European bullhead, Cottus sp. Environ Pollut 184:917 (2014).

[28] Bado-Nilles A, Quentel C, Mazurais D, Zambonino-Infante JL, Auffret M, ThomasGuyon $\mathrm{H}$, et al. In vivo effects of the soluble fraction of light cycle oil on immune functions in the European sea bass, Dicentrarchus labrax (Linné). Ecotoxicol Environ Saf 74:1896-904 (2011).

[29] Lomba L, Muniz S, Pino MR, Navarro E, Giner B. Ecotoxicity studies of the levulinate ester series. Ecotoxicology 23:1484-93 (2014).

[30] Roberts BL, Wyman Dorough H. Relative toxicities of chemicals to the earthworm Eisenia foetida. Environ Toxicol Chem 3:67-78 (1984).

[31] Junek R, Morrow R, Schoenherr JI, Schubert R, Kallmeyer R, Phull S, et al. Bimodal effect of humic acids on the LPS-induced TNF- $\alpha$ release from differentiated U937 cells. Phytomedicine 16:470-6 (2009)

[32] Bado-Nilles A, Techer R, Porcher JM, Geffard A, Gagnaire B, Betoulle S, et al. Detection of immunotoxic effects of estrogenic and androgenic endocrine disrupting compounds using splenic immune cells of the female three-spined stickleback, Gasterosteus aculeatus (L.). Environ Toxicol Pharmacol 38:672-83 (2014).

[33] ECHA. 5-(methoxymethyl)-2-furaldehyde - Registration Dossier - ECHA. https://echa.europa.eu/fr/registration-dossier/-/registered-dossier/10620 [accessed February 13, 2018].

[34] Muralidhara A, Tosi P, Mija A, Sbirrazuoli N, Len C, Engelen V, et al. Insights on thermal and fire hazards of humins in support of their sustainable use in advanced biorefineries, ACS Sustain Chem \& Eng., 2018 (DOI: 10.1021/acssuschemeng.8b03971) 
Table 1: Summary of tests performed for regulatory purposes (REACH regulation Annex VII)

\begin{tabular}{|c|c|c|c|c|c|}
\hline Organisms & Effect & Endpoints & Expression of results & Test duration & Test methods \\
\hline $\begin{array}{l}\text { Micro-algae } \\
\text { Pseudokirchneriella } \\
\text { subcapitata }\end{array}$ & Chronic & Growth & $\begin{array}{l}\text { EC10 } \\
\text { EC50 }\end{array}$ & 72 hours & OECD 201, 2011 \\
\hline $\begin{array}{l}\text { Micro-crustaceans } \\
\text { Daphnia magna }\end{array}$ & Acute & Mobility & EC50 & 48 hours & OECD 202, 2004 \\
\hline $\begin{array}{l}\text { Activated sludge } \\
\text { receiving predominantly } \\
\text { domestic sewage }\end{array}$ & $\begin{array}{c}\text { Ready } \\
\text { Biodegradability }\end{array}$ & $\begin{array}{c}\text { Oxygen } \\
\text { consumption }\end{array}$ & $\%$ biodegradation & 28 days & OECD 301F, 1992 \\
\hline
\end{tabular}


Table 2: Results of ecotoxicity and biodegradability tests

\begin{tabular}{|c|c|c|c|c|c|c|c|c|}
\hline \multirow[t]{2}{*}{ Compounds } & \multicolumn{3}{|c|}{$\begin{array}{c}\text { Daphnia magna } \\
\text { OECD } 202\end{array}$} & \multicolumn{4}{|c|}{$\begin{array}{c}\text { Pseudokirchneriella subcapitata } \\
\text { OECD } 201 \\
\end{array}$} & \multirow{2}{*}{$\begin{array}{c}\text { Ready } \\
\text { Biodegradability } \\
\text { OECD 301F }\end{array}$} \\
\hline & $\begin{array}{c}\text { EC50 24h } \\
\left(\mathrm{mg} \cdot \mathrm{L}^{-1}\right)\end{array}$ & $\begin{array}{c}\text { EC50 48h } \\
\left(\mathrm{mg} \cdot \mathrm{L}^{-1}\right)\end{array}$ & $\begin{array}{c}95 \% \\
\text { confidence } \\
\text { interval }\end{array}$ & $\begin{array}{l}\text { EC10 72h } \\
\left(\mathrm{mg} \cdot \mathrm{L}^{-1}\right)\end{array}$ & $\begin{array}{l}95 \% \\
\text { confidence } \\
\text { interval }\end{array}$ & $\begin{array}{c}\text { EC50 72h } \\
\left(\mathrm{mg} \cdot \mathrm{L}^{-1}\right)\end{array}$ & $\begin{array}{l}95 \% \\
\text { confidence } \\
\text { interval }\end{array}$ & \\
\hline ML & $>500^{*}$ & $>500^{*}$ & - & $\approx 500^{*}$ & - & $>500^{*}$ & - & 81 \\
\hline HMF & $>500^{*}$ & 36.5 & $30.0-45.1$ & 28.0 & $26.0-30.5$ & 110.2 & $106.8-115.5$ & 82 \\
\hline MMF & $>200^{*}$ & 29.6 & $28.5-30.5$ & N.T** & N.T** & N.T** & N.T** & 3.9 \\
\hline $\begin{array}{l}\text { RMF (crude } \\
\text { MMF) }\end{array}$ & $\approx 500 *$ & 13.0 & $10.7-15.7$ & 29.6 & $26.6-32.4$ & 79.2 & $80.6-108.8$ & 12.4 \\
\hline Humins (a) & $>500 *$ & 203.2 & $180.1-225$ & 37.6 & $34.9-43.7$ & 51.5 & $49.0-53.0$ & 36.4 \\
\hline Humins (b) & $>500^{*}$ & 213.4 & $108.6-214$ & 50.4 & $47.9-51.7$ & 59.7 & $56.3-69.3$ & 37.2 \\
\hline
\end{tabular}

\footnotetext{
* highest tested concentration

** not tested
} 


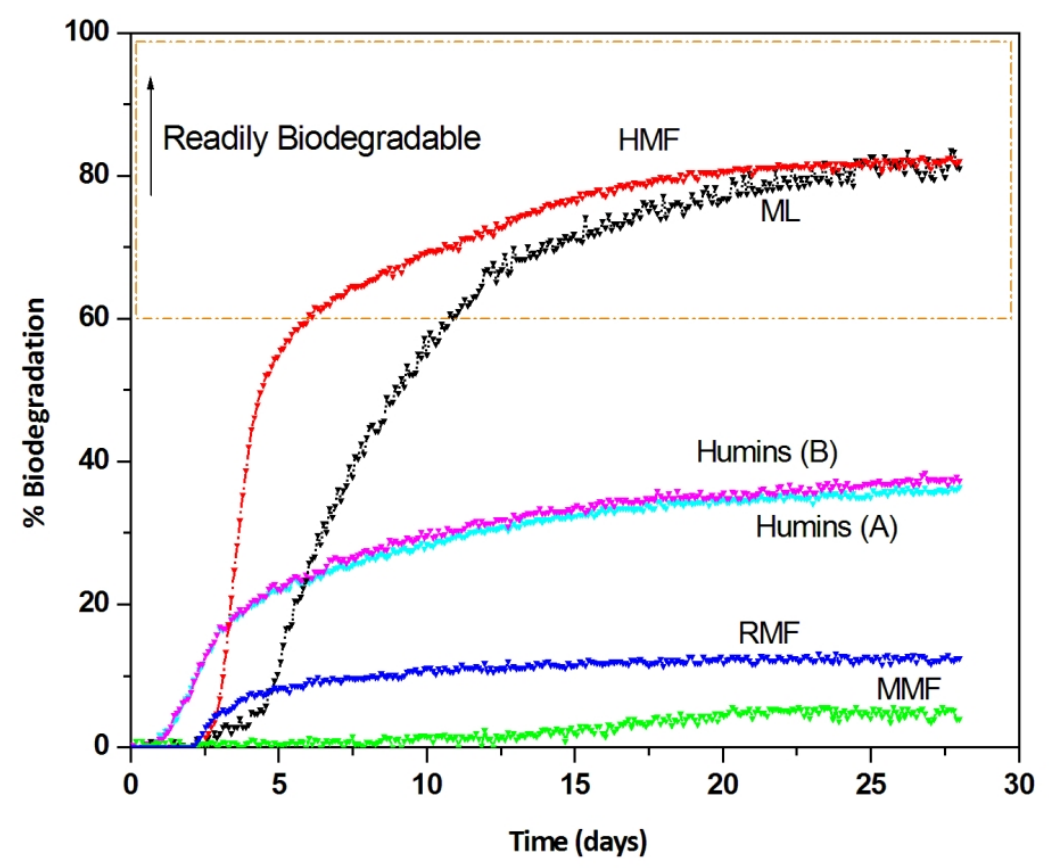

Figure 1: Biodegradability profile of Humins a, Humins $b, M L, H M F, M M F$ and RMF. 


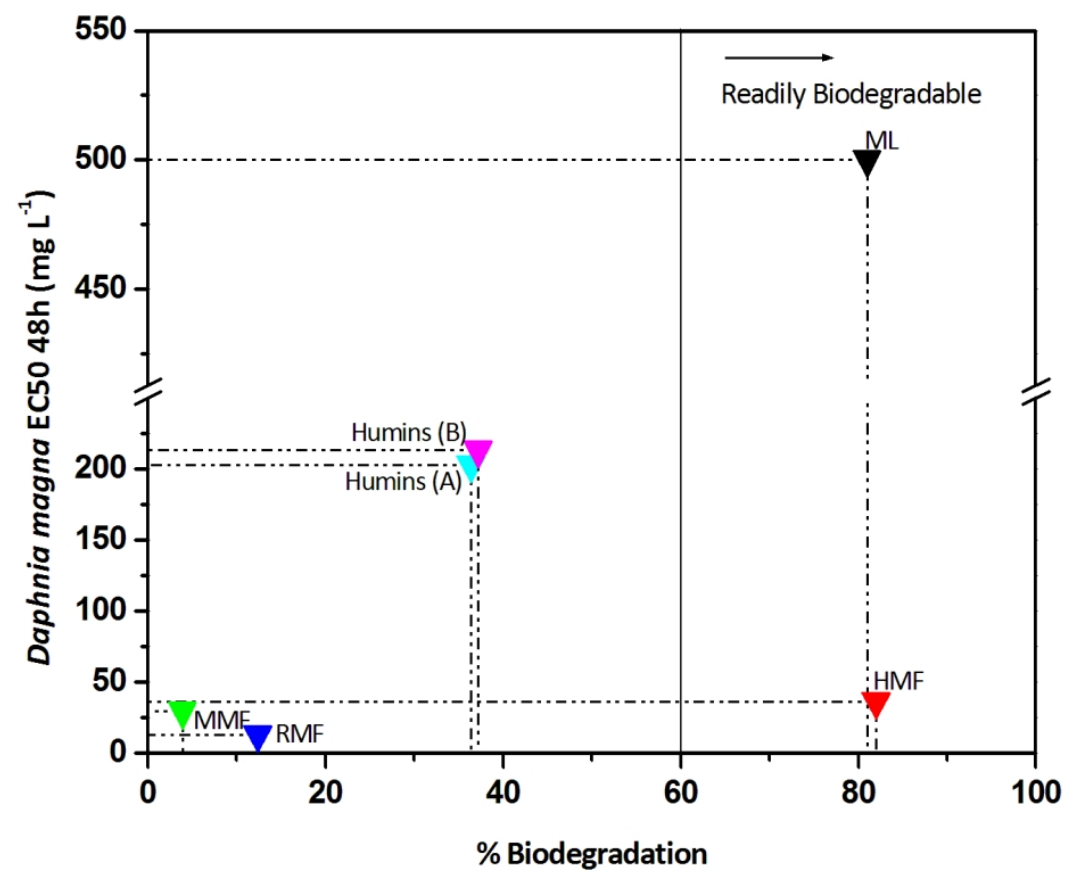

Figure 2: Relationship between biodegradability and toxicity profiles (EC50 48h) of all tested compounds. 